\title{
Diphtheria in Europe
}

\author{
BY W. KWANTES \\ Public Health Laboratory Diphtheria Reference Service, Public Health Laboratory, \\ Cockett Road, Swansea, Wales, SA2 OFA
}

\section{SUMMARY}

A letter of inquiry was sent to 21 countries in Europe to ascertain their experience of diphtheria during the last 20 years. An analysis of the 15 replies showed that all relied on childhood vaccination and that this had reduced the annual incidence of the disease to a very low level. There was mention of three epidemics during the last ten years, and three countries identified several cases of skin diphtheria, mostly in patients who had contracted infection abroad.

\section{INTRODUCTION}

'The diphtheria bacillus was first grown in pure culture by Loeffler in 1884.' So began the first paragraph in a textbook of clinical pathology in 1900 (Levy \& Klemperer, 1900). Loeffler's name is now seldom remembered on account of this, but for his bacteriological medium, which is still used for studying the morphology of corynebacteria.

There has been a considerable change in the method of diagnosis of diphtheria since the Second World War. Forty years ago when I first qualified in medicine the diagnosis was clinical and made on four criteria. The extent and spread of the membrane, the presence of oedema, the foetor of the breath and the presence of adenitis (Harries \& Mitman, 1940). Antitoxin was given immediately and a swab was taken. This was put on to a Loeffler serum slope and spread on to blood agar and tellurite agar plates, and the laboratory was expected to confirm the diagnosis within $24 \mathrm{~h}$. This was made on microscopic and colonial morphology and required a certain amount of experience.

Nowadays there are few clinicians who can recognize the foetor of the breath in a case of diphtheria. In this respect I must mention a case of diphtheria which occurred in a small village in South Wales in 1962. The trainee medical practitioner who first saw the patient at his home was worried on account of the toxicity and sent for his superior. The latter on entering the house took one sniff and said 'Diphtheria'! He had not seen a case for over ten years.

Diphtheria can look like any other form of tonsillitis. Early in the illness there is only a small spot of membrane, often unilateral. Except in mild cases, this spreads as a greyish yellow membrane over one or both tonsils. There is an associated toxicity which if untreated may result in death, particularly in infants and young children. Many medical practitioners no longer consider diphtheria as a possibility and I know of instances of death occurring before a diagnosis was made. 
Because of the scarcity of the disease the diagnosis has changed from a clinical one to a bacteriological one, the differential diagnoses being streptococcal sore throat and infectious mononucleosis. Microbiologists also have difficulty in recognizing both the microscopic and colonial morphology of Corynebacterium diphtheriae and may take several days to establish a diagnosis. Occasionally this is first made by the reference laboratory receiving the strain. This delay in diagnosis makes it all the more important to immunize the entire population because mortality in young children may be as high as $30 \%$ if antitoxin is not given early.

Immunization has completely changed the incidence of diphtheria in the world and particularly in Europe. There are however areas where diphtheria is still in evidence, and skin diphtheria is now becoming an important reservoir of infection.

In the United Kingdom most cases of diphtheria are sporadic and originate from abroad. A letter of inquiry was sent to 21 European countries in order to find out if their experiences were similar to those in the U.K.

\section{METHOD}

A standard letter was sent to each of the heads of the Institutes of Hygiene or Public Health Departments in 21 countries in Europe, asking about the notifications of diphtheria over the last 20 years, the vaccination schedule and if they had experienced any interesting aspects of the disease.

Replies were received from 15, namely Austria, Belgium, Denmark, Czechoslovakia, Finland, France, West Germany, Greece, Hungary, Italy, the Netherlands, Portugal, Sweden, Switzerland and Yugoslavia. The replies were varied but all were in the English language and there were a number of interesting comments.

Information for the United Kingdom was obtained from the Public Health Laboratory Service Communicable Disease Surveillance Centre.

\section{RESULTS}

\section{Incidence}

An analysis of the notifications of diphtheria divided into five-year groups for each of the countries is given in Table 1 . It will be seen that the annual incidence has dropped from 16 to about $0 \cdot 2$ per million over the last 20 years. With such low figures it is obvious that no clinician, epidemiologist or bacteriologist can gain experience in the disease unless he happens to be involved in an outbreak, which nowadays is a seldom occurrence.

As in the United Kingdom, most countries are at present only experiencing sporadic diphtheria. From 1980 only five countries mentioned deaths from diphtheria. There were eight in Germany in 1980-3. There was one in Portugal in 1980, one in England and one in Hungary in 1982 and one in the Netherlands in 1983.

\section{Outbreaks}

Switzerland had a small outbreak in 1974 with no recorded death (Wegmann et al. 1977). Portugal also had an outbreak in Lisbon during 1976 involving over 500 persons, with about 40 recorded deaths. There was a small one in Germany in 1982 with five recorded deaths (Public Health Laboratory Service no. 18, 1983). All were in areas with records of low immunization against diphtheria. 
Table 1. Number of cases of diphtheria in European countries, 1964-83

$\begin{array}{lrrrrr} & \begin{array}{c}\text { Population } \\ \text { (millions) }\end{array} & 1964-8 & 1969-73 & 1974-8 & 1979-83 \\ \text { Austria } & 8 & 137 & 80 & 17 & 1(1979-82) \\ \text { Belgium } & 10 & 423 & 146 & 31 & 1(1979-81) \\ \text { Czechoslovakia } & 15 & 294 & 46 & 3 & 5 \\ \text { Denmark } & 5 & 1 & 0 & 0 & 1 \\ \text { Finland } & 5 & 0 & 0 & 0 & 0 \\ \text { France } & 54 & 975 & 207 & 94 & 13 \\ \text { W. Germany } & 62 & 1629 & 313 & 188 & 69(1979-82) \\ \text { Greece } & 10 & 3262 & 642 & 26 & 1(1979-80) \\ \text { Hungary } & 11 & 196 & 17 & 38 & 9(1979-82) \\ \text { Italy } & 57 & 14340 & 3102 & 1184 & 92(1979-80) \\ \text { Netherlands } & 14 & 7 & 4 & 3 & 3 \\ \text { Portugal } & 10 & 5366 & 1076 & 1831 & 124(1979-82) \\ \text { Sweden } & 8 & 0 & 1 & 3 & 12 \\ \text { Switzerland } & 6 & 72 & 41 & 484 & 8 \\ \text { United Kingdom } & 56 & 86 & 58 & 17 & 14 \\ \text { Yugoslavia } & 22 & 3021 & 592 & 31 & 10 \\ \quad \text { Total } & 353 & 29809 & 6325 & 3950 & 363 \\ \text { Cases/annum/million } & & 16 & 4 \cdot 5 & 2 \cdot 5 & 0 \cdot 2\end{array}$

Figures in parentheses give the years included.

In the Swiss outbreak there were about 400 persons affected but it was mentioned that in most cases the disease was mild and a number of them were bacteriological isolations from immunized persons, which should not really have been classified as notified cases. The outbreak was controlled by antibiotic protection of contacts and widespread immunization of the population.

The German outbreak was caused by a much more virulent strain. There were five deaths among the 16 notifications. The fact that the younger medical practitioners had never encountered the disease delayed both the diagnosis and specific treatment with antitoxin.

A comment was received from Hungary reporting two symptomless school 'outbreaks' of non-clinical diphtheria in immunized children occurring in 1978 and 1982. Investigators took throat swabs for another reason and during 1978 found 25 out of 138 children carrying toxinogenic $C$. diphtheriae. In 1982 they found 50 out of 100 carrying a toxinogenic strain. None had any clinical illness.

Belgium had a similar experience. A longitudinal study of symptomless carriage was undertaken in Brussels in 1978-80. Among 300 healthy children aged 3-12 years with a low socio-economic status, 61 carried $C$. diphtheriae on one or more occasions. Five of the strains were toxinogenic.

A survey was carried out in Athens in 1979 (Sapounas, 1981) when 895 schoolchildren were investigated. Seven symptomless carriers of non-toxigenic strains were found. There was no isolation of toxinogenic strains.

\section{Immunization against diphtheria}

The vaccination schedules of the countries were compared and found to be very similar. Most immunized their infants against diphtheria with three doses of a vaccine combined with poliomyelitis and tetanus during the first year of life, usually in the third, fourth and fifth months. The first booster was given during 
the second year, except in Czechoslovakia and Hungary where it was given when the child was 3 years old. In Denmark only three doses of a combined vaccine were given. These were at 5, 6 and 15 months of age with no booster dose given later.

A second booster was usually given at school entry at age 4-6 and about half the countries, including Austria, Czechoslovakia, West Germany, Hungary, the Netherlands, Switzerland and Yugoslavia, gave a third booster between the ages of 9 and 15. Hungary was considering discontinuing the latter as a result of antibody studies.

The Netherlands, Sweden and Yugoslavia mentioned their vaccination uptake rate, which was about $95 \%$. Vaccination is compulsory in Yugoslavia but not in the other two countries. In England and Wales about $85 \%$ of infants are vaccinated during the first year of life.

\section{Skin diphtheria}

Three countries mentioned the presence of skin diphtheria, the Netherlands, West Germany (Ippen, 1983) and Sweden (Kindmark \& Schwann, 1978).

The Netherlands identified seven cases of cutaneous diphtheria, two in each of the years 1970 and 1977 and one each in the years 1978, 1979 and 1980. They found that six of the seven cases of cutaneous diphtheria had been fully immunized.

West Germany described three cases of skin diphtheria, two in 1976/77 and one in 1983. The latter came from Kenya.

From 1978 to 1981 Sweden identified 12 patients with cutaneous diphtheria. Seven were Swedish and five were foreigners. Only two strains were found to be toxinogenic and these were from foreigners. In 11 the country where infection took place was known. Four were refugees from South East Asia, three were from the Maldive Islands, two from Tokyo and one each from India and the West Indies.

Finland, which has been free from diphtheria for the last twenty years, admitted the possibility of the importation of skin diphtheria. They thought the diagnosis could easily be missed by physicians because the disease had not been seen there.

\section{DISCUSSION}

If Loeffler were alive today he should be well satisfied with the progress which has taken place since he first cultivated the diphtheria bacillus exactly one hundred years ago. All the countries in Europe which replied to my letter can be pleased with the virtual disappearance of clinical diphtheria. The number of cases per annum in each country has dropped to single figures in all except Italy, West Germany and Portugal, where it is only slightly above this level.

There is now only an occasional death from the disease. When one occurs, as it did in England in 1982 (Public Health Laboratory Service no. 3, 1983), it is a tragedy for the family but unfortunately very newsworthy. My laboratory was invaded by the press and television cameras and public statements were required. This is an experience for which one is not prepared and completely upsets the work of the department. It can only be avoided by ensuring a high immunity amongst the population. Efforts must be made in all countries of the world to attain and possibly better the $95 \%$ immunization rate of the three European countries mentioned. 
I wish to thank the following, all of whom went to the trouble of answering my letter of inquiry in detail in the English language: Professor H. Flamm, Vienna; Dr G. Thiers, Brussels; Dr V. I. Kodat, Prague; Drs H. Zoffmann and T. Ronne, Copenhagen; Dr T. Kuronen, Helsinki; Dr R. Netter, Paris; Professor H. Ph. Pöhn, West Berlin; Dr V. Danielides, Thessaloniki; Dr I. Dömök, Budapest; Dr D. Greco, Rome; Dr H. Bijkerk, Leidschendam; Dr Laura Ayres, Lisbon; Dr Victoria Romanus, Stockholm; Dr B. Somaini, Bern; Professor G. Jakob, Sarajevo.

\section{REFERENCES}

Harries, E. H. R. \& Mitman, M. (1940). Clinical Practice in Infectious Diseases. Edinburgh: Livingstone.

IPPEN, H. (1983). Haut-Diphtherie. Dermatosen 31, 5-10.

Kindmark, C.-O. \& Schwan, Anna (1978). Huddifteri - en ingalunda ofarlig men lätt förbised sjukdom. Lakartidningen 75, 680-682.

LeVy, E. \& KLEMPERER, F. (1900). Elements of Clinical Bacteriology for Physicians and Students. Translated by A. Eshner. Philadelphia: Saunders.

Public Health Laboratory Service (1983). Communicable Disease Reports. No. 3.

Public Health Laboratory Service (1983). Communicable Disease Reports. No. 18.

Sapounas, T. (1981). Epidemiology of diphtheria carriers among schoolchildren in Athens. Doctoral Thesis, Athens University.

Wegmann, T., Baerlocher, K., Geel, O., Krech, U., Schmid, E., Flury, F., Krahenmann, P., Thurlimann, R. \& Wegmann, A. (1977). Ostschweizer Diphtherie-Epidemie 1974. Schweizerische medizinische Wochenschrift 107, 455-464. 